\title{
Structure and expression pattern of the murine Hox-3.2 gene
}

\author{
JÖRN R. ERSELIUS, MARTYN D. GOULDING and PETER GRUSS \\ Max-Planck-Institute of Biophysical Chemistry, Department of Molecular Cell Biology, 3400 Gottingen, FRG
}

\section{Summary}

The murine homeobox-containing gene Hox-3.2 is the most $5^{\prime}$ member of the Hox-3 complex on chromosome 15 isolated to date. Conceptual translation of the longest ORF gives a protein of $\mathbf{2 6 0}$ amino acids lacking the conserved hexapeptide found in most homeobox genes. Northern analysis detects three transcripts of 1.5, 1.9 and $3.2 \mathrm{~kb}$ in day 9 to 15 p.c. embryos. As early as day 8.5 p.c., transcripts can be detected in the posterior part of the embryo by in situ hybridization. At this developmental stage no or only very weak expression is visible in the neural plate. At day 10.5 Hox-3.2 is detected in the ventral part of the neural tube with a sharp anterior boundary at the level of the third thoracic prevertebra. This anterior boundary remains at day 12.5 and day 14.5. In contrast to $H o x-3.1, H o x-3.2$ is not expressed in the dorsal horns containing the sensory neurons at day 14.5 p.c. Hox-3.2 transcripts are also detected in the posterior prevertebrae, the hindlimb buds and the cortex of the developing kidney. Unlike $H o x-1.4$ and $H o x-1.3$ and their paralogs, Hox-3.2, -2.5 and $4.4(5.2)$ show strikingly different anterior boundaries of expression in the CNS and prevertebrae.

Key words: in situ hybridization, homeobox, Hox-3, mouse embryogenesis, paralogous genes.

\section{Introduction}

The homeobox is a highly conserved $180 \mathrm{bp}$ sequence, which was first described in genes controlling pattern formation in Drosophila melanogaster (McGinnis et al. 1984; Scott and Weiner, 1984; reviewed by Akam, 1987 and Gehring, 1987). This $180 \mathrm{bp}$ sequence normally located close to the $C$-terminus of the protein, encodes a 60 amino acid homeodomain containing a helix-turnhelix motif that functions as a sequence-specific DNAbinding domain (Desplan et al. 1985; Laughon and Scott, 1984; Fainsod et al. 1986; Cho et al. 1988; Hoey and Levine, 1988; Otting et al. 1988; Qian et al. 1989).

To date, more than 30 murine homeobox genes (Hox genes) have been isolated due to their homology to the Antennapedia (Antp) homeobox or other members of this highly conserved gene family (for review see Kessel and Gruss, 1990). Many of these genes are arranged in clusters, in Drosophila as well as in vertebrates (for review see Akam, 1989). Four clusters have been identified in the mouse genome, the Hox-1 cluster on chromosome 6 (Colberg-Poley et al. 1985a; Duboule et al. 1986), the Hox-2 cluster on chromosome 11 (Hart et al. 1985; Graham et al. 1988), the Hox-3 cluster on chromosome 15 (Awgulewitsch et al. 1986; Breier et al. 1988 ) and the Hox-4 cluster on chromosome 2 (Duboule and Dolle, 1989; the nomenclature for the Hox -5 cluster has been recently updated and the cluster was renamed as Hox-4; Hox-5.1=Hox-4.2, Hox-5.2= Hox-4.4, Hox-5.3=Hox-4.5; see Duboule et al. 1990; we will use the new nomenclature, but give the old names in brackets). These clusters can be aligned on the basis of homologies between the homeobox sequences. The identical order of paralogous genes (Schughart et al. 1988) in all four clusters suggests that they emerged by complete or partial duplication of a common ancestral cluster (Kappen et al. 1989). Moreover, alignment can be extended to the Drosophila ANT-C and $B X-C$ complexes (Gaunt et al. 1988; Duboule and Dolle, 1989; Graham et al. 1989). A strong correlation exists between the position of a gene within the cluster and its expression pattern along the anteroposterior (A-P) axis both in Drosophila and vertebrates (Akam, 1989). The more 3' a gene is located in the cluster, the more anterior is its border of expression in the developing embryo. In the mouse, this is most obvious in the central nervous system, where distinct anterior boundaries of expression are exhibited (Gaunt $e t$ al. 1988; Duboule and Dolle, 1989; Graham et al. 1989). Recently it has been reported that the paralogous genes, Hox-1.4, -2.6 and -4.2 (5.1) as well as Hox-1.3, -2.1 and -3.4 display similiar anteroposterior boundaries of expression in the developing CNS and prevertebrae, although some tissue-specific differences exist (Gaunt et al. 1989; 1990). Since these genes are found toward the $3^{\prime}$ end of the cluster, it was of interest to determine whether paralogous genes at the $5^{\prime}$ end of the cluster also show similar anterior boundaries of expression.

Two recent reports have highlighted the potential role of homeobox genes in specifiying positional information in the developing vertebrate embryo. The 
Xenopus $X l H b o x 1$ gene encodes two transcripts that produce 'long' and 'short' proteins. These proteins are expressed in the cervical region of Xenopus embryos. When antibodies to the 'long' protein were injected into single-cell embryos, the anterior spinal cord was transformed into a hindbrain-like structure. The long and short proteins appear to act antagonistically, since after injection of mRNA for the short protein into the embryo a similar phenotype is observed (Wright et al. 1989). Ectopic expression of the murine Hox-1.1 gene in transgenic mice results in cranofacial abnormalities and variations of cervical vertebrae (Balling et al. 1989; Kessel et al. 1990). It occurs that both ectoderm and mesoderm derivatives are affected: cranial neural crest cells and the first cervical somites. Specifically the derivatives of the first cervical somite are altered in these mice, resulting in the manifestation of an extra vertebra (Kessel et al. 1990). Thus the additional presence of $H o x-1.1$ interferes with embryogenesis in a disruptive and reprogramming fashion. These results suggest that altered homeobox gene expression in vertebrates can lead to transformations very similar to the homeotic transformations observed in Drosophila mutants. This indicates an important role of these genes in vertebrate pattern formation.

In this study we present a detailed analysis of the mouse Hox-3.2 gene and its expression during murine development. Hox-3.2 is the most 5' gene in the Hox-3 cluster isolated to date and is located approximately $8 \mathrm{~kb}$ upstream of Hox-3.1 (Breier et al. 1988; Le Mouellic et al. 1988). Using Northern and in situ hybridization the temporal and regional pattern of Hox3.2 expression was analysed during mouse development from day 8.5 to day 16.5 of gestation. Transcripts were detected in the posterior part of the neural tube starting at the level of the third thoracic prevertebra (T3), in prevertebrae posterior to $\mathrm{T} 9$, the proximal part of the hindlimb buds and the developing kidney, which continues to express Hox-3.2 in the adult tissue. The restricted pattern of Hox-3.2 expression during this time is consistent with Hox-3.2 specifying positional information in the mouse embryo. This study also reveals that important differences exist in the expression of paralogous genes and in the expression of genes within each gene cluster.

\section{Materials and methods}

\section{cDNA library screening}

Approximately $1.5 \times 10^{6}$ clones of a $\lambda g t 10$ cDNA library prepared from 8.5 day p.c. mouse embryo RNA (Fahrner $e t$ al. 1987) were screened under high stringency conditions by hybridization using a random oligo-labelled (Feinberg and Vogelstein, 1983) $180 \mathrm{bp}$ genomic fragment containing the first 154 bp of the Hox-3.2 homeobox (Breier et al. 1988). Hybridization conditions were as follows: $6 \times \mathrm{SSC}, 0.5 \%$ SDS, $5 \times$ Denhardts, $0.1 \mathrm{mg} \mathrm{m}^{-1}$ denatured salmon sperm DNA, $65^{\circ} \mathrm{C}$. Filters were washed in $2 \times \mathrm{SSC}, 1 \%$ SDS for $30 \mathrm{~min}$ followed by two further washes for $30 \mathrm{~min}$ in $0.1 \times \mathrm{SSC}$, $0.1 \%$ SDS at $65^{\circ} \mathrm{C}$.

\section{DNA sequence analysis}

Subclones of the Hox-3.2 cDNA and overlapping subclones of the genomic DNA were generated both in M13 mp18 and M13 mp19. The nucleotide sequence was determined by the dideoxy chain termination method (Sanger et al. 1977) using an M13 sequencing kit (Sequenase, US Biochemicals).

\section{Isolation of cells, tissues, embryos and RNA}

PCC7 cells were grown as monolayers in Dulbecco's modified Eagles media supplemented with $10 \%$ foetal calf serum. Cells were either induced to differentiate into neuroepithelium by treating them with retinoic acid alone $\left(5 \times 10^{-7} \mathrm{M}\right)$ or into neuronal-like cells by treating them with retinoic acid and dibutyryl cAMP $\left(10^{-3} \mathrm{M}\right)$. Six days after initiating treatment cells were analyzed for the presence of neuroepithelial- or neuronal-like cells.

Embryos for Northern and in situ analysis were obtained from natural matings of female NMRI mice. The day of the vaginal plug was designated as day 0 p.c. Tissues were isolated from adult NMRI mice. Total RNA was isolated by homogenizing cells, tissues or embryos in guanidinium thiocyanate and poly $(\mathrm{A})^{+}$RNA was obtained after elution from oligo (dT)-cellulose columns according to Ausubel et al. (1989).

\section{Northern blotting}

Samples containing $10 \mu \mathrm{g}$ of poly $(\mathrm{A})^{+}$RNA were denatured at $68^{\circ} \mathrm{C}$, separated on $1 \%$ agarose-formaldehyde gels and transferred to Hybond $\mathrm{N}$ (Amersham) nylon membranes using $10 \times$ SSC. Nucleic acids were crosslinked under $309 \mathrm{~nm}$ UV light and the filters were then hybridized under high stringency conditions. Hybridization conditions were as follows: $7.5 \%$ dextran sulfate, $5 \times \mathrm{SSC}, 5 \times$ Denhardts, $50 \%$ deionized formamide (FA), $1 \%$ SDS, $10 \mathrm{~mm}$ Tris-HCl $\mathrm{pH} 7.5,0.1 \mathrm{~mm}$ sodium pyrophosphate, $0.1 \mathrm{~mm}$ ATP and $0.1 \mathrm{mg} \mathrm{ml}^{-1}$ denatured salmon sperm DNA. Filters were hybridized at $42^{\circ} \mathrm{C}$ for $16 \mathrm{~h}$. Filters were washed in $2 \times \mathrm{SSC}$, $1 \%$ SDS at $65^{\circ} \mathrm{C}$ followed by $0.1 \times \mathrm{SSC}, 0.1 \% \mathrm{SDS}, 65^{\circ} \mathrm{C}$ for $30 \mathrm{~min}$.

\section{In situ hybridization}

Radioactive probes were transcribed in vitro from linearized plasmid containing the first $361 \mathrm{bp}$ of the Hox-3.2 cDNA using $0.1 \mathrm{mCi}{ }^{35} \mathrm{~S}$-UTP and $0.1 \mathrm{mCi}{ }^{35} \mathrm{~S}-\mathrm{CTP}$ and $\mathrm{T} 3$ or $\mathrm{T} 7$ polymerases (Promega Biotech.). After DNase I digestion, probes were precipitated with $10 \%$ trichloracetic acid and collected on nitrocellulose filters (Millipore). Probes were eluted from the filters in $50 \mathrm{~mm}$ EDTA pH $8,0.1 \%$ SDS at $65^{\circ} \mathrm{C}$ for $30 \mathrm{~min}$. Following ethanol precipitation probes were partially degraded with $0.2 \mathrm{M} \mathrm{NaOH}$ on ice for $30 \mathrm{~min}$, neutralized with $1 \mathrm{M}$ acetic acid and ethanol precipitated. Finally, the probes were resuspended in $50 \%$ FA, $10 \mathrm{~mm}$ DTT. Sections $(8 \mu \mathrm{m})$ were prepared and hybridized as described (Hogan et al. 1986; Dony and Gruss, 1987). Sections were cut with a cryostat and transferred to subbed slides. Sections were quickly dried at $50^{\circ} \mathrm{C}$, fixed in $4 \%$ paraformaldehyde (PFA) and dehydrated in a graded ethanol series. Slides were stored at $-20^{\circ} \mathrm{C}$ until the day of hybridization. Prior to hybridization, slides were dipped in distilled water and incubated for $30 \mathrm{~min}$ in $2 \times S S C$ at $70^{\circ} \mathrm{C}$. After a second rinse with water, slides were digested with $0.125 \mathrm{mg} \mathrm{m}^{-1}$ pronase for $10 \mathrm{~min}$ at RT. Digestion was stopped in $0.2 \%$ glycine for $30 \mathrm{~s}$. Slides were rinsed in PBS and refixed in $4 \%$ PFA for $20 \mathrm{~min}$, rinsed again in PBS and acetylated for $10 \mathrm{~min}$ in $0.1 \mathrm{M}$ triethanolamine with $1 / 400$ volume of acetic acid. After rinsing slides in PBS, sections were dehydrated in 
graded ethanol and air dried for $1-2 \mathrm{~h}$. The probe was diluted to a final concentration of $5 \times 10^{6} \mathrm{cts} \mathrm{min}^{-1} \mathrm{ml}^{-1}$ in a buffer containing $50 \%$ FA, $2 \times \mathrm{SSC}, 10 \mathrm{~mm}$ Tris, $10 \mathrm{~mm} \mathrm{NaPO}_{4}$ pH6.8, $5 \mathrm{~mm}$ EDTA, $10 \%$ dextran sulphate, $150 \mu \mathrm{g}$ tRNA ml ${ }^{-1}, 150 \mu \mathrm{g}$ denatured salmon sperm DNA, $0.1 \mathrm{~mm}$ UTP, $10 \mu \mathrm{M}$ S-ATP, $1 \mathrm{~mm}$ ADP $\beta$ S, $10 \mathrm{~mm}$ DTT, and $10 \mathrm{~mm}$ $\beta$-mercaptoethanol. The hybridization mix was boiled for $2 \mathrm{~min}$, applied directly onto sections and covered with siliconized cover slips. Slides were hybridized overnight in a humid chamber at $48^{\circ} \mathrm{C}$. Following hybridization slides were washed for $2-4 \mathrm{~h}$ in $50 \%$ FA, $2 \times$ SSC and $10 \mathrm{~mm}$ $\beta$-mercaptoethanol at $37^{\circ} \mathrm{C}$ followed by RNase digestion. A second wash in $50 \%$ FA, $2 \times \mathrm{SSC}, 10 \mathrm{~mm} \beta$-mercaptoethanol was done overnight followed by dehydration through a graded ethanol series. Slides were dipped in Kodak NTB-2 emulsion (diluted $1: 1$ with water) and exposed for $8-12$ days at $4^{\circ} \mathrm{C}$. Development was done at RT for $3 \mathrm{~min}$ in Kodak D-19, followed by $1 \mathrm{~min}$ in $1 \%$ acetic acid and $3 \mathrm{~min}$ in $30 \%$ sodium thiosulphate. After repeated washes in distilled water slides were stained with Giemsa, dried and coverslips applied. Photomicrographs were taken using a Leitz Labovert brightfield/dark-field microscope.

\section{In vitro transcription and translation}

Plasmid containing the complete Hox-3.2 cDNA was linearized and sense and antisense strands were synthesized with either $\mathrm{T} 3$ or $\mathrm{T} 7$ polymerase (Promega). The reaction conditions were $40 \mathrm{~mm}$ Tris- $\mathrm{HCl} \mathrm{pH} 8,8 \mathrm{~mm} \mathrm{MgCl}, 25 \mathrm{~mm}$ $\mathrm{NaCl}, 2 \mathrm{~mm}$ spermidine, $5 \mathrm{~mm}$ DTT, $2 \mathrm{~mm}$ dNTPs, $2 \mathrm{~mm}$ $\mathrm{m}^{7} \mathrm{G}\left(5^{\prime}\right) \mathrm{ppp} 5^{\prime} \mathrm{G}, 2 \mu \mathrm{g}$ DNA template and $2 \mu \mathrm{l}$ enzyme. Approximately $1 / 50$ of the RNA template was then translated in a rabbit reticulocyte lysate according to the manufacturer's specifications (Promega) using $\left[{ }^{35} \mathrm{~S}\right]$ methionine (Amersham) to label the protein.

\section{Results}

\section{Characterization of the Hox-3.2 cDNA and its genomic structure}

The characterization of the murine Hox-3.2 homeobox has been recently reported (Breier et al. 1988). To obtain Hox-3.2 cDNAs, a 180 bp probe, containing the first 154 bp of the Hox-3.2 homeobox was used to screen a $\lambda$ gt 10 cDNA library, prepared from 8.5 days p.c. mouse embryo poly (A) ${ }^{+}$RNA (Fahrner et al. 1987). Hybridization under high stringency conditions led to the isolation of several positive cDNA clones. The complete nucleotide sequence of the longest cDNA $(1450 \mathrm{bp})$ is shown in Fig. 1A. This cDNA contains a typical polyadenylation signal at position 1412 (AATAAA; Birnstiel et al. 1985) and the longest open reading frame (ORF) consists of $791 \mathrm{bp}$ (nucleotide position 337-1128).

Three ATG codons (nucleotide position 349, 625 and 772) were found in frame with the homeobox. The surrounding nucleotide sequence of all three matches only poorly to the consensus sequence established for eukaryotic translational start (CCACCAUGG; Kozak, 1986). In such cases the ATG codon that lies closest to the $5^{\prime}$ end should be favoured (Kozak, 1978, 1983). Use of the first ATG would produce a protein consisting of 260 amino acids, containing the homeodomain close to its carboxyl terminus. The close proximity of the homeodomain to the $3^{\prime}$ end of the protein has been reported also for other vertebrate homeo proteins (Kessel et al. 1987; Krumlauf et al. 1987; Fibi et al. 1988; Odenwald et al. 1987; Breier et al. 1988; Bogarad et al. 1989; Rubin et al. 1987; Meijlink et al. 1987; Schughart et al. 1988).

A cosmid clone (kindly provided by B. Herrmann) containing genomic sequences from the Hox-3 cluster was used to establish the primary structure of the Hox3.2 gene. The Hox-3.2 homeobox is located about $8 \mathrm{~kb}$ upstream of the Hox-3.1 homeobox. Digestion of this cosmid with a variety of restriction enzymes and subsequent hybridization under high stringency conditions either with the Hox-3.2 homeobox-probe or 5' probes of the cDNA (probe 1: nucleotides 1-361; probe 2: nucleotides 637-905) identified Hox-3.2 coding sequences. The structure of the genomic region encoding the $1.45 \mathrm{~kb} H o x-3.2 \mathrm{cDNA}$ is shown in Fig. 1B. Comparison of homologous fragments derived from the cDNA and genomic clones identified a single intron of approximately $1.7 \mathrm{~kb}$ in the Hox -3.2 coding sequence. The fragments surrounding the splice junctions were isolated (the $700 \mathrm{bp} A p a \mathrm{I}-A p a \mathrm{I}$ fragment at the 5'splice junction and the $800 \mathrm{bp} \mathrm{BamHI-BamHI}$ fragment at the 3 'splice junction), subcloned and sequenced. The sequences at the $5^{\prime}$ splice site (AG/ TAAGTT) and the 3'splice site (TTTGTCCCTCCAG/ GT) are in good agreement with the splice consensus (5': AG/GT ${ }_{G}^{A}$ AGT; 3 : : ${ }^{\mathrm{T}}{ }_{C}{ }^{\mathrm{T}}{ }_{C} \mathrm{TT}^{\mathrm{T}}{ }_{C}{ }^{\mathrm{T}}{ }^{\mathrm{T}}{ }^{\mathrm{T}}{ }^{\mathrm{T}}{ }^{\mathrm{T}}{ }^{\mathrm{T}}{ }^{\mathrm{T}}{ }_{C}$ NCAG/G; Shapiro and Senapathy, 1987). Thus, the Hox-3.2 gene consists of two exons of approximately 900 and $550 \mathrm{bp}$ separated by an intron of $1.7 \mathrm{~kb}$. The first exon encodes at least $350 \mathrm{bp}$ of $5^{\prime}$ untranslated sequence and 179 amino acids, whilst the second exon encodes 81 amino acids including the homeodomain and a 3 'untranslated region of $300 \mathrm{bp}$.

Unlike the Hox-4 (-5) cluster, where Hox-4.5 (-5.3) is located about $6 \mathrm{~kb}$ upstream of Hox-4.4 (-5.2), the paralog of Hox-3.2, no additional homeobox could be detected within $20 \mathrm{~kb}$ upstream of $H o x-3.2$ by using Hox-3.1, Hox-3.2, Hox-1.1 or Antp homeobox probes and low stringency hybridization conditions (Duboule and Dolle, 1989). This indicates that loss of such a gene from the Hox-3 cluster may have occurred after duplication from the ancestral complex or alternatively that the Hox-3 cluster arose by partial duplication.

\section{The predicted Hox-3.2 protein}

The putative Hox-3.2 protein, as deduced by conceptual translation of cDNA sequences encodes a protein of 260 amino acids, with a predicted relative molecular mass of $29.3 \times 10^{3}$. In order to confirm this, the complete Hox-3.2 cDNA was transcribed and translated in vitro using $\left[{ }^{35} \mathrm{~S}\right]$ methionine to label the protein. The resulting protein mix was analysed by SDSpolyacrylamide gel electrophoresis and autoradiography. The observed relative molecular mass was approximately $33 \times 10^{3}$ (Fig. 2). Since homeobox-containing genes migrate in general slower than expected (Kessel et al. 1987), the obtained relative molecular mass is consistent with the use of the first ATG codon. 
A IIox-3.2 cDNA

1 CAC ACG GTC AAG GGG GGG GGG TCC CTG ATG AGA TAT GAT TCG TCC 46 GGG GAG GGG GGG CTG TCT GGC GCC TTG GGT CCA GAG TTG CAA ATC 91 GCC AGG AMA ACG CAG GTC GCG GGG ATC AGC MAA GAG MAg GGg GCG 136 GTA AMG GGG GGA MM AGC AAG GGG GMA MMA MAG CCC CTG CGC ATT

181 GAT CCG CGC CGT ATT TTT GGG TAA ATA CGA TCA CGT GGG GGC TGG

226 GGA CCG CGC CGT ATT TTTC GGG TAAA GATA CGA TCA CGT COG GGC TGC

226 GGA ACC AAT GAG CTG CCG GGA AAA GGE TGG MA AAT MAT TAC CTG
271 CCT TGA TTG TTC TGT GAG CAG ATA MAA AGT ACA TAT ACA GTT CAT

316 ACA ATA ATC TTA TGT ATG TAA MAC CCT GTT ACG ATG TCG GCG ACG

361 GGG CCC ATC AGT MAC TAT TAC GTG GAC TCG CTC ATC TCT CAC GAC Gly pro Ile Ser asn tyr tyr val Asp Ser Leu Ile Ser H1s Asp

106 MAT GAA GAC CTC CTA GCG TCC AGG TTT CCG GCC ACC GGG GCT CAC Asn Glu Asp Leu leu Ala Ser Arg Phe Pro Ala Thr Gly Ala His

151 CCT GCC GCC GCC AGA CCC AGC GGC TTG GTG CCG GAC TGT AGC GAT pro Ala Ala Ala Arg pro Ser gly leu val pro Asp Cys Ser Asp

196 TTT CCG TCC TGT AGC TTC GCG CCC MAG CCG GCT GTA TTC AGT ACG Phe Pro Ser Cys Ser phe Ala pro lys pro Ala Val phe Ser Thr

541 TCG TGG GCG CCG GTG CCC TCG CAG TCG TCT GTG GTC TAT CAC CCT Ser Trp Ala pro Val pro Ser Gln Ser Ser val Val Tyr hi. pro

506 TAC GGC CCC CAG CCC CAC CTC GGC GCC GAC ACG CGC TAC ATG CGG Tyr Gly pro Gln pro His Leu Gly Ala Asp Thr Arg Tyr met Arg

631 ACT TGG CTC GA GA CCG CTG TCC GGC GCC GTC TCC TTC CCC AGC TTC Thr Trp Leu Glu pro Leu ser Gly ala Val ser phe pro ser phe

676 CCG GCC GGG GGC CGT CAC TAC GCC CTC AAG CCC GAC GCC TAC CCG Pro Ala Gly Gly arg his tyf Mla Leu Lys pro Asp na tyr pro

721 GGG CGC CGC GCC GAC TGC GGC CCG GGC GAC GGC CGC AGC TAC CCG gly Arg Arg Ala Asp Cys Gly pro gly Asp Gly arg ser tyr pro

766 GAC TAC ATG TAC GGC TCG CCC GGG GAA CTG CGC GAC CGC GCC CCG Asp Tyr met tyr Gly Ser pro gly Glu heu Arg Asp Arg Ala pro

811 CAg ACG CTG CCC TCG CCC GAG GCG GAC GCG CTG GCC GGC AGC Ma Gln Thr Leu Pro Ser Pro Glu Na Aap Ala Leu Ala Gly Ser Lya

- 56 cac ma gag Gag ma gCc gac ctg gac cct agc

901 AAC TGG ATC CAC GCC CGT TCC ACA AGG MG MG CGC TGC CCC TAC Asn Trp Ite His Ala Arg Ser Thr Arg hys Lys Arg Cys pro tyr

946 ACC MG TAC CAG ACG CTG GMA CTG GAG MG GAG TTT CTC TTC MAT Thr Lys Tyr Gln Thr Leu Glu Leu Glu Lys Glu Phe Lou Phe Aan

991 ATG TAT TTA ACC AGG GAC CGT CGG TAC GAG GTG GCC CGT GTT CTC Met Tyr Leu Thr Arg Asp Arg Arg Tyr Glu Val Ala Arg Val Leu

1036 AAT CTC ACT GAG CGG CAG GTC MA ATC TGG ITT CAG MC CGG AGG Asn Leu Thr Glu Arg Gln Val Lys Ile Trp Phe Gin Asn Arg Arg

1081 ATG MA ATG MA MG ATG AAT MA GAC MA ACC GAC MG GM CM met Lys Met Lys bys met Asn lys Glu bys Thr Aap lys Glu Gin

1126 TCC TAA GCC CTG CCC CAG ACT GCT GCC TCG GCA CAG CCA AGG GM Ser End

1171 ACA CM NM CCC CCA CM MA ATG CCC CA CCC AGG CGG GAG AM 1216 GCA CGA MMA GM MMG GM AGA ACA AGA TAG AGA AMA GCC CAC CGT 1261 CTT MA AAG MA AGA MM MA NGG MA GGG MM MAT GCA MC TCT 1306 TGC GAT GTG GGA GGG TTA AGT GTT GAC MAA TTG GTG TTT MGA GTT 1351 AGT TCT ATC CAT CGA GGA GGA GGC AGG AGA GM ACT GCG TTC TCT 1396 TCC CCA GCG CAA CTG MM TAM ATC ACA CAC ACA MAT GTG MM AM 1411 MA MA MA

B

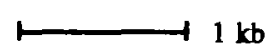

Fig. 1. (A) Hox-3.2 cDNA sequence and putative primary structure of the $H o x-3.2$ protein. The last STOP codon (TAA) before the translational start site and the polyadenylation signal (AATAAA) are underlined. The homeodomain is boxed. Restriction sites used for isolating probes are given (nucleotide $1-A p a \mathrm{I}=$ probe 1 , XhoI-Bam $\mathrm{HI}=$ probe 2 ; compare Fig. 1B). (B) Genomic structure of the Hox-3.2 gene. The distance between the Hox-3.1 and $H o x-3.2$ homeobox is approximately $8 \mathrm{~kb}$. Homeobox sequences are indicated as black boxes. The Hox-3.2 transcription unit consists of two exons interrupted by a $1.7 \mathrm{~kb}$ intron $5^{\prime}$ of the homeobox. Probes 1 and 2 used for in situ hybridization are marked by bold lines. Some restriction sites are given (compare Fig. 1A).

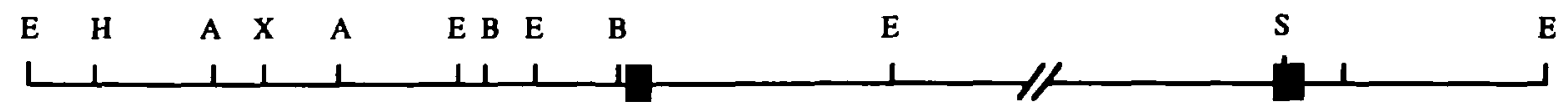

Hox-3.2

Hox-3.1
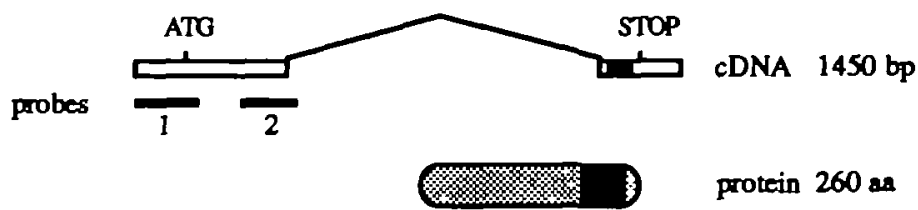

$\begin{array}{ll}E=\text { Boo R I } & B=\text { Bam H I } \\ A=\text { Apa I } & H=\text { Hind III } \\ X=\text { Xho I } & S=\text { Sal I }\end{array}$




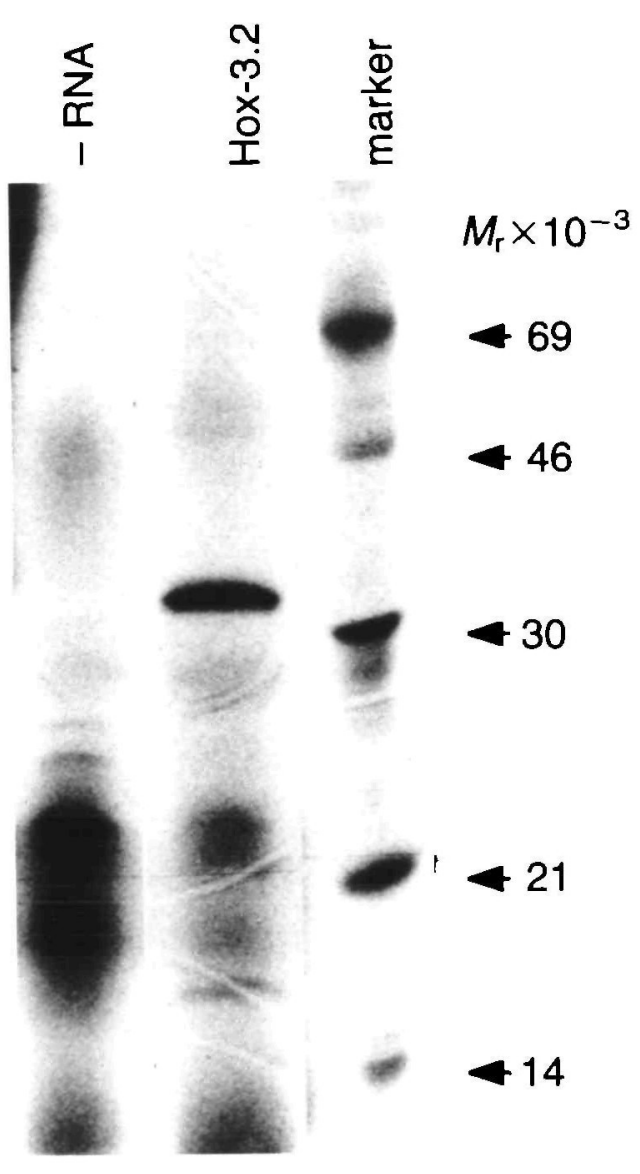

Fig. 2. In vitro translated Hox-3.2 protein. The complete cDNA sequence was transcribed and translated in vitro in a rabbit reticulocyte lysate using $\left[{ }^{35} \mathrm{~S}\right]$ methionine to label the protein. The first lane shows the control reaction without RNA, lane 2 the Hox 3.2 protein and lane 3 the marker (Rainbow mol. wt marker, Amersham).

The Hox-3.2 homeodomain shows the highest homology to Hox-1.7 (Rubin et al. 1987), Hox-2.5 (Bogarad et al. 1989) and Hox-4.4 (-5.2) (Dollé and Duboule, 1989), the paralogs of Hox-3.2 (Duboule and Dolle). The homology to Hox-1.7 and Hox-2.5 extends up to the splice site ( $9 / 11$ amino acids) with the position of the splice site being conserved as well. Hox-3.2 lacks the conserved hexapeptide (IleTyrProTrpMetArg), which is usually found upstream of the splice site in the exon preceding the homeobox-containing exon (Baron et al. 1987; Kessel et al. 1987; Krumlauf et al. 1987; Meijlink et al. 1987; Odenwald et al. 1987; Breier et al. 1988; Fibi et al. 1988; Le Mouellic et al. 1988; Schughart et al. 1988). The hexapeptide is also absent in the paralogs of Hox-3.2, Hox-1.7 (Rubin et al. 1987) and Hox-2.5 (Bogarad et al. 1989) and in the homologous gene of Hox-3.2 in Xenopus, XlHbox 6 (Sharpe et al. 1987).

The homeodomain of Hox-3.2 and its paralogs are slightly more similar to the Drosophila $A b d-B(43 / 60$ amino acids; Regulewski et al. 1985; Celniker et al. 1989 ) than the Antp homeodomain (42/60 amino acids).
However, when the sequences are aligned, it becomes clear that the $A b d-B$ and $H o x-3.2$ paralogous homeodomains are clearly distinct from the Antp homeodomain (Duboule and Dollé, 1989).

\section{Northern analysis}

The expression pattern of Hox-3.2 during mouse development was analysed by Northern blot analysis of poly $(\mathrm{A})^{+}$RNA from teratocarcinoma cell lines, mouse embryos and adult mouse tissues. The same probe used for cDNA isolation was utilized to detect Hox-3.2 transcripts. This probe detected a single band in Southern blot analysis of mouse genomic DNA under high stringency conditions excluding cross-hybridization to other homeobox genes (data not shown).

Fig. 3A shows the hybridization under stringent conditions of the Hox-3.2 probe to RNA from day 9-16 p.c. embryos. Two major transcripts of 1.5 and $1.9 \mathrm{~kb}$ and a minor transcript of $3.2 \mathrm{~kb}$ were detected. Transcripts of Hox-3.2 are most abundant in day 10-12 p.c. embryos. Later than day 13 of gestation, expression decreases sharply and by day 16 no Hox-3.2 mRNA was detected by Northern blot analysis. Weak expression was observed in day 9 p.c. embryos and in in situ hybridization of 8.5 day embryos. These results, as well as the isolation of $H o x-3.2 \mathrm{cDNAs}$ from an 8.5 day p.c. embryonic library, demonstrate that Hox-3.2 is expressed as early as day 8.5 of embryogenesis. The $5^{\prime}$ cDNA-probe 1 (nucleotide 1-361) detects only the two major transcripts, indicating that the $3.2 \mathrm{~kb}$ transcript is probably the result of alternative splicing. However, we have isolated an additional Hox-3.2 cDNA where the polyadenylation signal at position 1412 was not utilized and continued for another $450 \mathrm{bp}$ at the $3^{\prime}$ end (data not shown). This suggests that the 1.5 and $1.9 \mathrm{~kb}$ transcripts may result from poly-A variation instead of alternative splicing.

We have also examined poly (A) ${ }^{+}$RNA derived from a variety of adult mouse tissues including lung, liver, kidney, heart, brain, testis, ovary, intestine and spleen for Hox-3.2 expression. The only adult tissue that expressed the Hox-3.2 gene was kidney, where a homeobox probe detected only the two major transcripts of 1.5 and $1.9 \mathrm{~kb}$ (data not shown).

The expression of Hox-3.2 was analysed in the murine teratocarcinoma cell line F9. F9 EC.stem cells can be differentiated in vitro into parietal endoderm by treatment with retinoic acid (RA) and dibutyryl cyclic AMP (cAMP). Unlike many other homeobox genes including Hox-1.3 and Hox-3.1 (Breier et al. 1986; Fibi et al. 1988), Hox-3.2 is neither expressed in F9 stem cells nor in F9 cells differentiated for 1 to 4 days (data not shown).

While RNA of undifferentiated PCC 7 cells contained no detectable Hox-3.2 transcripts even after prolonged exposure of the Northern blot (data not shown), three Hox-3.2 transcripts were observed in RNA from PCC 7 cells differentiated either into neuroepithelial-like cells by RA treatment or into neuron-like cells in the presence of RA and cAMP (Fig. 3B) using the Hox-3.2 homeobox probe. These 
Fig. 3. (A) Northern blot analysis of Hox-3.2 during murine development. Approximately $10 \mu \mathrm{g}$ of embryonal poly (A) ${ }^{+}$RNA (day 9-day 16) were loaded in each lane. The three transcripts of $1.5,1.9$ and $3.2 \mathrm{~kb}$ are marked by arrowheads. Three independently prepared Northern blots have been hybridized and in each case all three transcripts were detected. An additional minor transcript of $2.6 \mathrm{~kb}$ was seen in this hybridization and it is unclear whether this transcript is derived from the Hox-3.2 gene. The blot was hybridized with a ${ }^{32} \mathrm{P}$-labelled homeobox-probe, which had been shown to hybridize to a single fragment on a genomic Southern blot. As a control, the blot was rehybridized with a Ha-ras probe. (B) Northern blot analysis of undifferentiated and differentiated PCC 7 cells. Lane 1: poly (A) ${ }^{+}$RNA from undifferentiated PCC 7 cells; lane 2: poly (A) ${ }^{+}$RNA from PCC 7 cells differentiated by retinoic acid into neuroepithelial-like cells; lane 3: poly (A) ${ }^{+}$RNA from PCC 7 cells differentiated by retinoic acid and dibutyryl cyclic AMP into neuron-like cells. The three transcripts are marked by arrowheads (compare Fig. 3A). As a control, the blot was rehybridized with a $\beta$-actin probe.

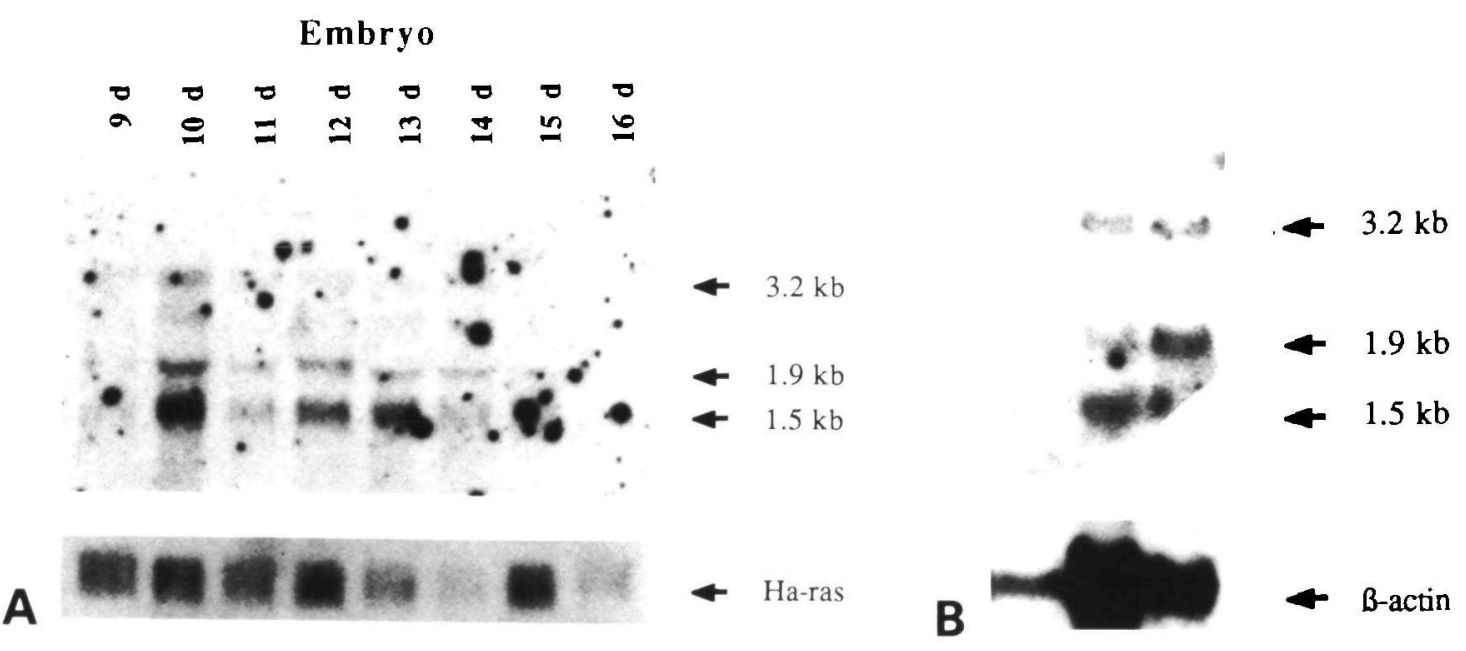

three transcripts were of the same size as those detected in the mouse embryo. Interestingly, expression of the Hox-3.2 gene was not seen in PC 12 cells, which can be also differentiated into neuron-like cells in the presence of NGF (data not shown).

\section{In situ hybridization}

In order to identify the spatial pattern of Hox-3.2 expression during embryogenesis, cryosections of day 8.5 to 16.5 p.c. embryos were hybridized with ${ }^{35} \mathrm{~S}$ labelled RNA probes generated from linearized plasmid containing the first $361 \mathrm{bp}$ of the Hox-3.2 cDNA (probe 1) or nucleotides 637-905 (probe 2). The two probes detected the same expression pattern, although probe 1 gave stronger signals. The specificity of the described results was controlled with Hox-3.2 sense probes which did not detect any specific signal (data not shown).

Expression was first detectable in 8.5 day embryos (Fig. 5A/B). At this stage the neural plate is still open throughout the posterior part of the embryo and consists only of undifferentiated neuroepithelial cells. There is little, if any, expression visible in cells of the neural plate, but a signal was seen at the base of the allantois.

By 10.5 days of development the neural folds have closed and consists mainly of a ventricular layer

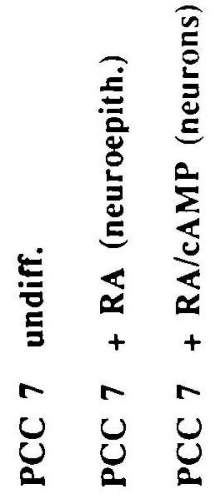

containing mitotically active cells. It is in the ventral region that the first cells start to migrate out into the newly formed mantle layer after they have undergone their last mitosis (Nornes and Carry, 1978; Wentworth, $1984 a, b$; Altman and Bayer, 1984). Expression of Hox3.2 was clearly restricted to this ventral part of the neural tube on transverse sections (Fig. 5C/D) and hybridization of a sagittal section of 10.5 day embryos exhibited the same pattern. Only the ventral part of the neural tube is positive for Hox-3.2 expression with an anterior boundary at the level of the third thoracic prevertebra (Fig. 4A/B). It is difficult to ascertain whether Hox-3.2 is expressed in spinal ganglia and

Fig. 4. Anterior-posterior boundaries of expression of Hox-3.2 and Hox-3.1 in day 10.5 and day 12.5 p.c. mouse embryos. (A,C,E,G) bright-field images; (B,D,F,H) darkfield images of $(A, C, E, G)$. (A,B) Sagittal section of a day 10.5 p.c. embryo hybridized with a Hox -3.2 antisense RNA probe. (C,D) Parasagittal section of a day 12.5 embryo hybridized with a $H o x-3.2$ probe. $(\mathrm{E}, \mathrm{F})$ Sagittal section of the same day 12.5 p.c embryo hybridized with a Hox-3.2 probe. $(G, H)$ Sagittal section of a day 12.5 p.c. embryo hybridized with a $H o x-3.1$ probe.

$\mathrm{mn}=$ metanephros, $\mathrm{nt}=$ neural tube, $\mathrm{sg}=$ spinal ganglia, $\mathrm{pv}=$ prevertebrae. $\mathrm{Cl}=$ first cervical, $\mathrm{T} 3=$ third thoracic and T6=sixth thoracic prevertebra. C1 and T3 mark the anterior boundaries of expression of Hox-3.1 and Hox-3.2 in the neural tube. 
Structure and expression pattern of Hox-3.2
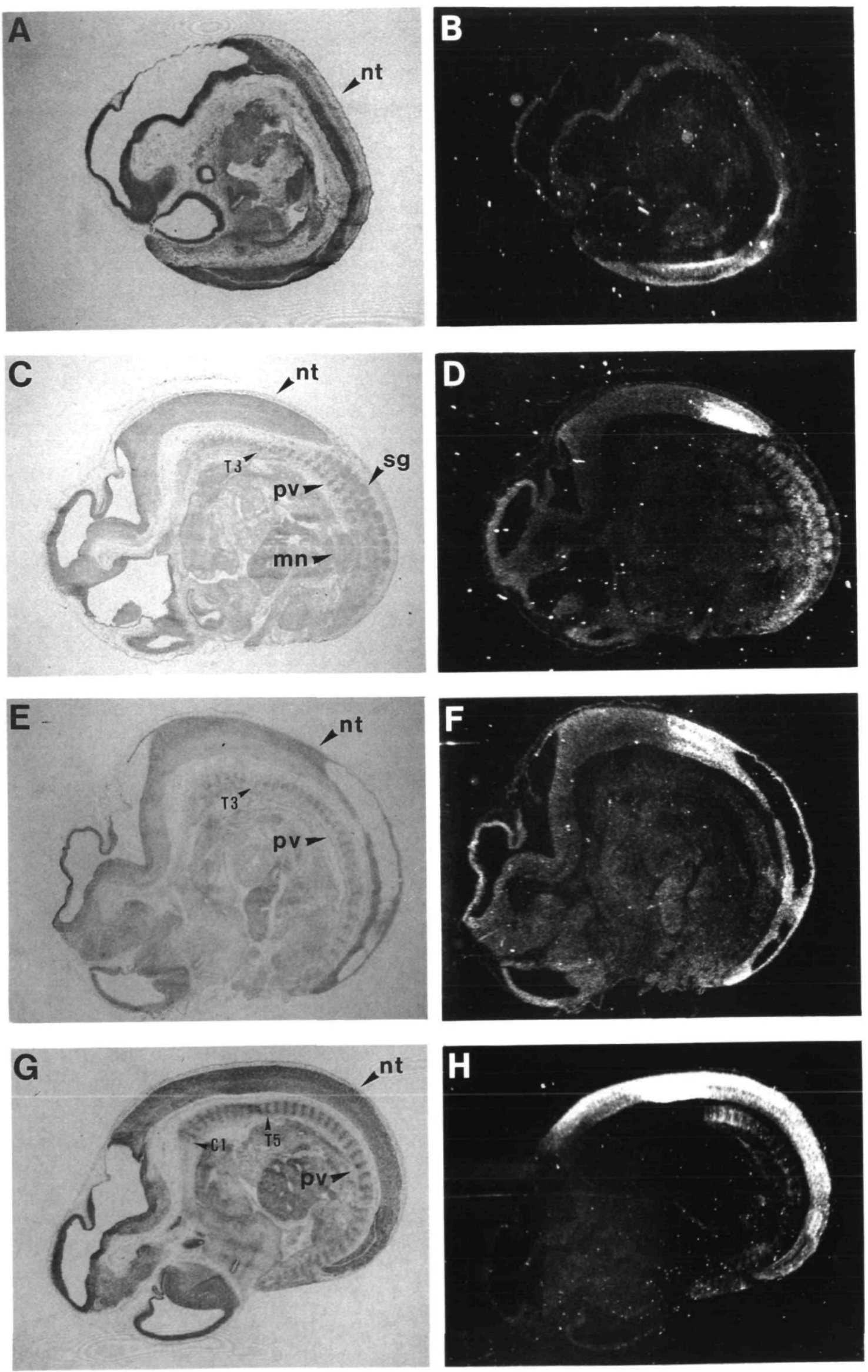
prevertebrae at this time since expression in these structures is very weak; however, it is clearly expressed at day 12.5 in both spinal ganglia and prevertebrae.

In day 12.5 embryos, Hox -3.2 transcripts were detected in the neural tube (Fig. $4 \mathrm{E} / \mathrm{F}$ ), the spinal ganglia, prevertebrae (Fig. 4C/D) and the proximal part of the hindlimb bud (not shown), while expression in the forelimbs has not been studied. Weak expression was also observed in the area where the metanephric tubules and metanephric ducts develop. As on day 10.5, expression in the neural tube was restricted to the posterior regions of the embryo and the sharp anterior boundary at the level of the third thoracic prevertebra was maintained. Transverse sections demonstrate that the signal in the neural tube was again seen only in postmitotic cells, including the mantle layer, marginal layer and the ventral horns, which contain the motor neurons (Fig. 5E/F). As with day 8.5 and day 10.5 embryos, the ependymal layer was negative for Hox-3.2 expression. In prevertebrae and spinal ganglia, the signal intensity was much lower than in the neural tube. The anterior boundary of expression in prevertebrae was difficult to define, since it was not as sharp as in the neural tube. Expression was more caudal, starting approximately at the ninth thoracic prevertebra.

By day 14.5 the dorsal horns containing sensory neurons have formed. The lumen of the neural tube is surrounded by a very thin ependymal layer with the neural tube consisting in the main of intermediate and marginal layers. Expression is very strong in these two outer layers of the neural tube, while the ependymal layer remains negative. Interestingly, the dorsal horns were clearly negative for Hox -3.2 expression and in the ventral horns expression was also considerably reduced compared to the mantle layer (Fig. $5 \mathrm{G} / \mathrm{H}$ ). The anterior boundary of expression was still maintained at the same level as in day 10.5 and day 12.5 embryos (data not shown).

These results were compared with the expression pattern of the next $3^{\prime}$ gene of the Hox-3 cluster, Hox3.1. In contrast to Hox-3.2, Hox-3.1 is expressed strongly in the dorsal horns at day 14.5 (Fig. 5I/K), while the expression pattern on transverse sections at earlier stages of development is very similar to Hox-3.2 (Breier et al. 1988; Le Mouellic et al. 1988). There were also important differences in the expression pattern along the A-P axis, where $H o x-3.1$ was expressed up to the first cervical vertebra in spinal cord and in the thoracic prevertebrae T5-T10 (Fig. 4G/H).

As mentioned above, Hox-3.2 is also expressed in the developing kidney starting at day 12.5. At day 14.5 and 16.5 expression is mainly found in the cortex, whereas in the mesenchyme the signal is considerably reduced (Fig. 6). Another strong positive signal, which could not be located unequivocally, was found close to the developing kidney at day 14.5 and appears to be either the ureter, umbilical cord or part of the genital ridge.

Thus, Hox-3.2 expression was found in mesodermand ectoderm-derived structures, but not in endoderm. Expression is first seen in mesoderm as early as day 8.5 and in ectoderm after the ventral horns start to form in the neural tube at day 9.5 (not shown). Kidney is the only adult organ where expression could be detected.

\section{Discussion}

This study describes the primary structure of the Hox$3.2 \mathrm{cDNA}$ and the expression pattern of the Hox-3.2 gene in murine embryogenesis. The Hox-3.2 gene represents the most $5^{\prime}$ member of the Hox -3 complex on mouse chromosome 15 identified to date. Although in the Hox-4 (-5) cluster the Hox-4.5 (-5.3) gene lies approximately $6 \mathrm{~kb}$ upstream of the paralog of Hox-3.2, namely $H o x-4.4$ (-5.2) (Duboule and Dollé, 1989), low stringency hybridization did not reveal any conserved homeobox sequence within the next $20 \mathrm{~kb}$ upstream of the Hox-3.2 gene, while the paralog of Hox-4.5 (-5.3) in the $H o x-1$ cluster, Hox-1.8 was identified under the same conditions (Haack et al. in preparation). Thus, it seems that the paralogs of $H o x-1.8$ and $-4.5(-5.3)$ appear to be absent from both the Hox-3 and Hox-2 clusters (Graham et al. 1989; this study). In this respect, the organization of the murine Hox gene clusters is very similar to the situation observed in human (Acampora et al. 1989), where only the human homologs of Hox-1.8 and $H o x-4.5(-5.3)$ are present. Further upstream two additional homeobox genes have been described in the human Hox -3 cluster suggesting that homologous genes are also present in mouse (Acampora et al. 1989).

Recently, attention has been drawn to the fact that the position of a gene within each cluster correlates with its anterior border of expression in the developing embryo (Gaunt et al. 1988; Duboule and Dollé, 1989; Graham et al. 1989; Dressler and Gruss, 1989). Thus, the more $5^{\prime}$ the position of a gene in the cluster the more posterior its domain of expression in the embryo. This is very similar to the genes of the Antp cluster in Drosophila, where genes at the $5^{\prime}$ end of the cluster are also expressed more posteriorly (Akam, 1989). The prediction of such a scenario is a posterior pattern of expression for the Hox-3.2 gene. Our results, showing expression of Hox-3.2 in the CNS posterior to the level of the third thoracic prevertebra (T3) and in sclerotomes posterior to $\mathrm{T} 9$, confirm this suggestion.

\section{The Hox-3.2 protein contains no hexapeptide}

Analysis of the predicted $H o x-3.2$ protein of 260 amino acids revealed a number of interesting features. As with the majority of homeodomain-containing proteins characterized to date, the homeodomain is situated close to the carboxyl terminus. Of the nine amino acids $3^{\prime}$ to the homeodomain, six are highly charged and may also contribute to an interaction with the target DNA. A further highly conserved domain of eleven amino acids is found immediately upstream of the homeodomain in the Hox-3.2, $-1.7,-2.5$ and XlHbox6 (Sharpe et al. 1987) genes but not the Drosophila counterpart $A b d-B$ (Celniker et al. 1989). This domain and the homeodomain are encoded by the second exon of the Hox 3.2 gene with the $5^{\prime}$ most amino acid forming the intron-exon junction. Outside of this extended 

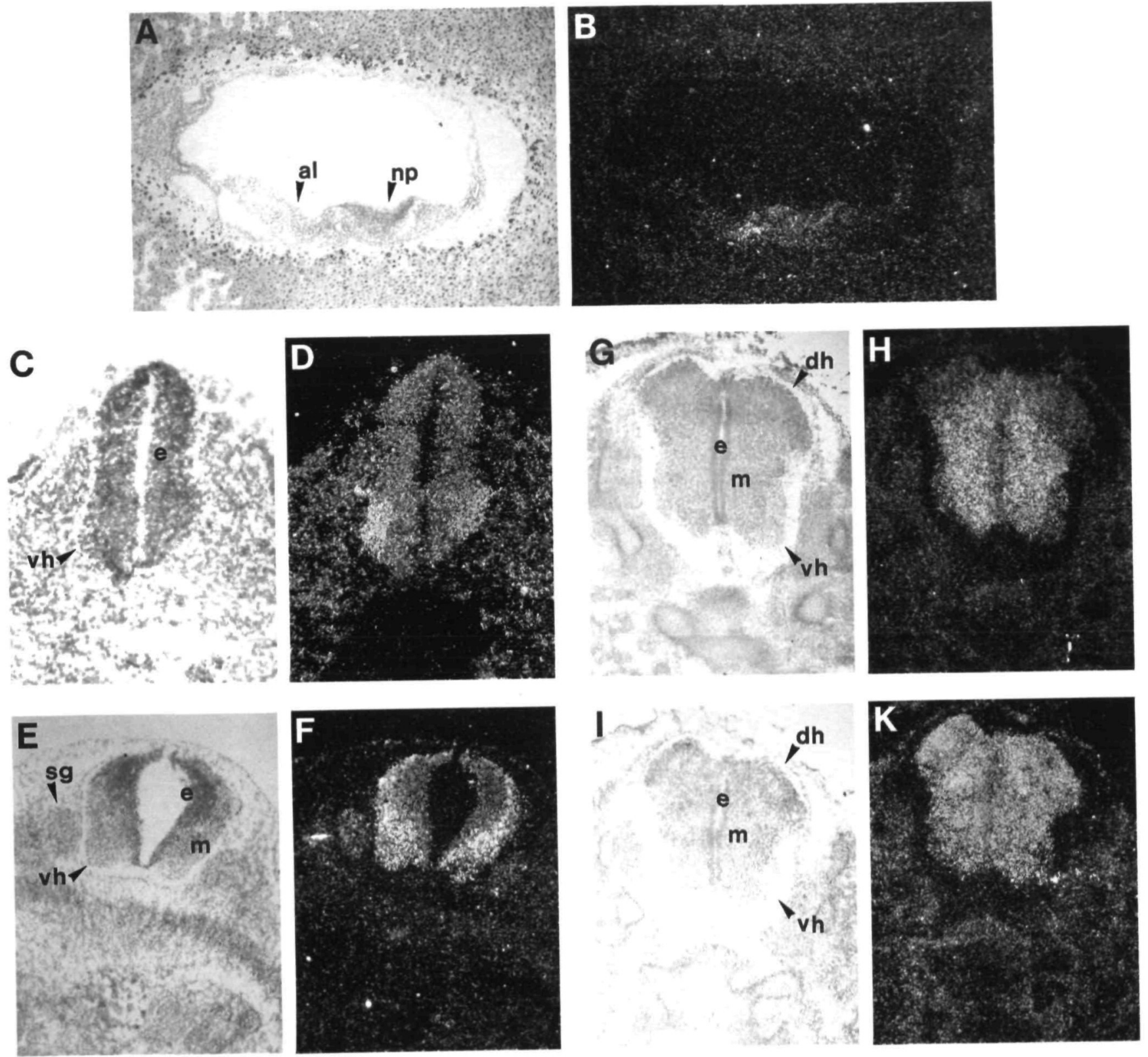

Fig. 5. In situ hybridization of Hox-3.2 (A-H) and Hox-3.1 (I,K) to transverse sections of day 8.5 to day 14.5 p.c. embryos. (A,C,E,G,I) Bright-field images; (B,D,F,H,K) dark-field images of (A,C,E,G,I). (A,B) Section through the posterior part of a day 8.5 p.c. embryo showing allantois and neural plate. (C,D) Section through a day 10.5 p.c. embryo at the level of the hindlimb buds. Formation of the ventral horns has started. (E,F) Section through a day 12.5 p.c. at the level of the 6th to 8th thoracic prevertebra. The ventral horns (containing motor neurons) have formed and the neural tube consists of a still large ependymal layer and the mantle layer. $(\mathrm{G}, \mathrm{H})$ Section through a day 14.5 p.c. embryo at the level of the 12th-13th thoracic prevertebra. The ependymal layer is reduced to a very thin layer of cells. The dorsal homs

(containing sensory neurons) have formed. $(\mathrm{I}, \mathrm{K})$ Nearby section to $(\mathrm{G}, \mathrm{H})$ hybridized with a Hox-3.1 probe. al=allantois, $\mathrm{dh}=$ dorsal horns, $\mathrm{e}=$ ependymal layer, $\mathrm{m}=$ mantle layer, $\mathrm{np}=$ neural plate, $\mathrm{sg}=$ spinal ganglia, vh=ventral horns 
. 
domain, there appears to be little homology between Hox -3.2 and its paralogs in mouse and other species. Unfortunately, the entire coding regions of the paralogs have not been reported, precluding a detailed analysis of regions outside these two domains. Nevertheless, the first 13 amino acids of $H o x-1.7$ and 50 amino acids of Hox-2.5 $5^{\prime}$ of the splice site as well as the amino terminal part of XlHbox6 show no extended conservation. This restricted homology seems to be typical for homologues of the Drosophila $A b d-B$ gene, since most murine homologues of other Drosophila genes show homologies also in regions outside the homeodomain (Akam, 1989). Interestingly, Hox-3.2 and the paralogous genes including $X l H b o x 6$ and $A b d-B$ contain no hexapeptide, a second highly conserved region besides the homeodomain, encoded by the exon preceding the homeodomain and present in most mouse homeodomain proteins. Other regions homologous between homeodomain proteins are often found at the amino terminus (Kessel et al. 1988) and the carboxy terminus, where many homeodomain proteins contain homopolymeric stretches of a single amino acid, e.g. glutamic acid in the Hox-3.1 protein (Breier et al. 1988), glutamine in
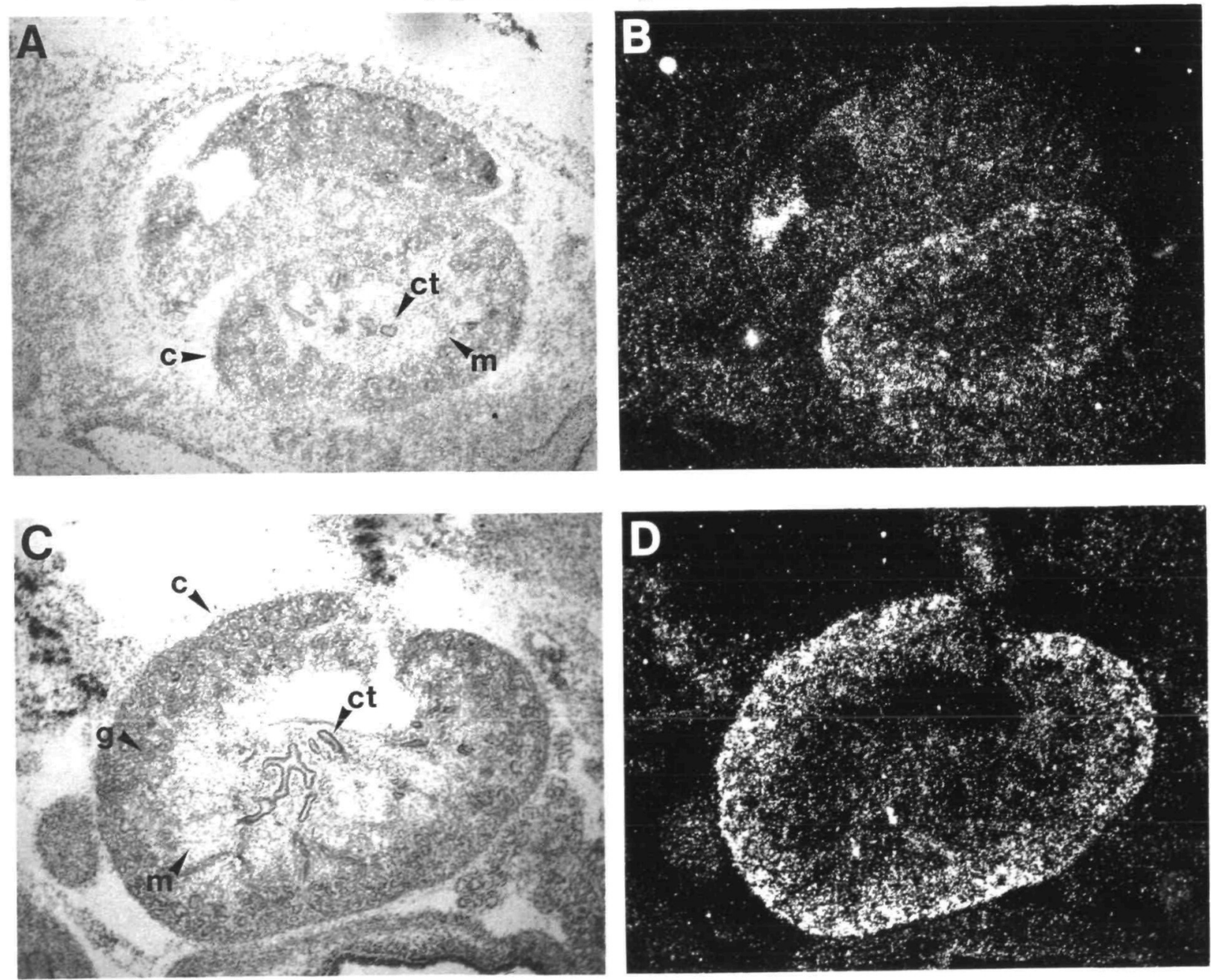

Fig. 6. Expression of Hox-3.2 in the developing mouse kidney. (A,C) Bright-field image; (B,D) dark-field image of (A,C). (A.B) Section through the developing kidney of a day 14.5 p.c. embryo. (C,D) Section through a 16.5 day p.c. kidney. $\mathrm{c}=$ cortex $\mathrm{ct}=$ collecting tubules, $\mathrm{g}=$ glomerulus, $\mathrm{m}=$ mesenchyme. 
activated by RA in the EC cell line NT2/D1 depending on their position in the cluster (Simeone et al. 1990), with genes at the $5^{\prime}$ end requiring much higher levels of RA (up to $10^{-5} \mathrm{M}$ ) for activation than genes in the $3^{\prime}$ part of the cluster $\left(10^{-8} \mathrm{M}\right)$. Although comparable experiments have not been done for $\mathrm{F} 9$ cells, it is interesting that the Hox-3.2 gene lying in the $5^{\prime}$ region of the cluster is not induced during differentiation of F9 cells, whereas the next $3^{\prime}$ gene, Hox-3.1, is activated by RA levels of $5 \times 10^{-7} \mathrm{M}$ in combination with $10^{-3} \mathrm{M}$ cAMP (Breier et al. 1986). The same is true for the Hox-1.7 gene, which cannot be induced (Rubin et al. 1987 ) by retinoic acid while the next $3^{\prime}$ member of the cluster Hox-1.1 is known to be expressed during retinoic-acid-induced F9 cell differentiation into parietal endoderm (Colberg-Poley et al. 1986).

It is worth noting that $H o x-3.2$ can be induced by retinoic acid in another embryonic carcinoma cell line PCC 7. These cells can be differentiated either into neuroepithelial-like cells by RA or neuron-like cells by RA and cAMP. Both differentiation procedures activate $H o x$-3.2. Thus, although $H o x$-3.2 does not respond to RA during differentiation of F9 cells into parietal endoderm, differentiation of PCC7 cells into 'ectodermal' cells induces Hox-3.2 expression, showing that only one of two retinoic-acid-mediated differentiation pathways involves activation of Hox-3.2.

\section{Temporally and spatially restricted expression during embryogenesis}

Consistent with a role in pattern formation, the Hox -3.2 gene exhibits a temporally and spatially restricted pattern of expression during embryogenesis. Quantitation by Northern hybridization revealed high levels of Hox-3.2 expression in mouse embryos from day 10 to 13 of gestation, whereas Hox-3.2 transcripts are absent in most tissues of the adult organism with the exception of kidney. Although, Hox-3.2 expression decreases at later stages in gestation, these analyses can be somewhat misleading, since at day 16.5, Hox-3.2 expression is confined to the spinal cord and cells in the cortex of the developing kidney. Consequently, the very localized expression of Hox-3.2 in these structures would account for the low levels of transcripts in Northerns of whole embryo RNA.

Many of the known murine homeobox genes encode multiple transcripts during embryogenesis (Odenwald et al. 1987; Rubin et al. 1987; Bogarad et al. 1989). While three transcripts of Hox-3.2 are found in the developing embryo, only the two major transcripts of 1.5 and $1.9 \mathrm{~kb}$ are found in the adult kidney. These tissue-specific differences are also seen with other homeobox genes, e.g. Hox-2.6, where the larger $4.1 \mathrm{~kb}$ transcript is present in embryo but not in lung, while the $2.4 \mathrm{~kb}$ transcript is found in both (Graham et al. 1989). It is possible that alternative splicing plays an important part in tissue-specific regulation of many of the vertebrate $H o x$ genes.

Delineation of the precise pattern of Hox-3.2 expression in the mouse embryo was undertaken by in situ analysis. Transcripts were first detected at day 8.5 of gestation in the posterior part of the embryo at the base of the allantois. From day 10 onward, expression of $H o x-3.2$ was observed in the ventral region of the neural tube, in postmitotic cells that have detached from the lumen of the neural tube and are migrating radially from the ventricular zone. It is here in the ventral horns that the motor neurons are born between day 9 and day 11 , followed by relay neurons between day 10 and day 12 and finally sensory neurons in the dorsal horns between day 12.5 and day 14.5 (Wentworth, 1984a, $b$; Altman and Bayer, 1984). This pattern of day 10.5 embryos is reflected again in day 12.5 embryos, where expression of Hox-3.2 is found predominantly in the intermediate zone. This layer of cells consists mainly of migrating and differentiating neuroblasts. Expression also appears in more dorsal regions of the neural tube in cells that will eventually settle in the intermediate grey of the adult spinal cord. This expression pattern persists in the day 14 to day 15 embryos with the dorsal funiculus and dorsal horns showing little or no expression of Hox-3.2 at a time when the dorsal horn neurons are being generated (Altman and Bayer, 1984). Very little expression is observed in the ventral and lateral funiculi at day 14 to day 15. Expression of Hox-3.2 throughout neurogenesis exhibits a predominance of expression in ventral regions of the neural tube but it seems unlikely that this pattern merely reflects the earlier maturation of neurons in the ventral neural tube. While expression in the ventral part of the neural tube at day 10.5 and the ventral and lateral regions of the neural tube at day 12.5 coincides with the birth of motor and relay neurons, at later times this expression persists and is absent from regions that will give rise to sensory interneurons. Compared to Hox-3.1 (Fig. 5I/K), Hox-3.2 shows a more restricted pattern of expression in the neural tube at day 14.5. Hox-3.1 at this stage is expressed throughout the intermediate zone in the day 14.5 neural tube including the region of the dorsal horns and substantía gelatinosa. Thus, although Hox-3.2 transcripts seem to be restricted to postmitotic cells, it is presently unclear what role Hox-3.2 might play in the differentiation and projection of neurons during neuronal development. Unlike members of the Pax gene family (Nornes et al. 1990) and Evx-1 (Bastian and Gruss, 1990), which are expressed in transversely restricted regions, Hox-3.2 is expressed over a wide transverse region within caudal regions of the neural tube. In this respect, Hox-3.2 expression in the neural tube appears more consistent with a role in specifying position than neuronal differentiation per se.

Transcripts of Hox-3.2 are not detected along the entire $\mathrm{A}-\mathrm{P}$ axis in the neural tube but are restricted to the posterior part caudal to the level of the third thoracic prevertebra. Low expression is seen in the same region in spinal ganglia. In contrast, expression of the next $3^{\prime}$ gene Hox-3.1 is more restricted in spinal ganglia to levels of T4 to T9 (Breier et al. 1988; Le Mouellic et al. 1988). On the other hand, the expression domain in the neural tube is much more extended. In this study, using an improved in situ hybridization 


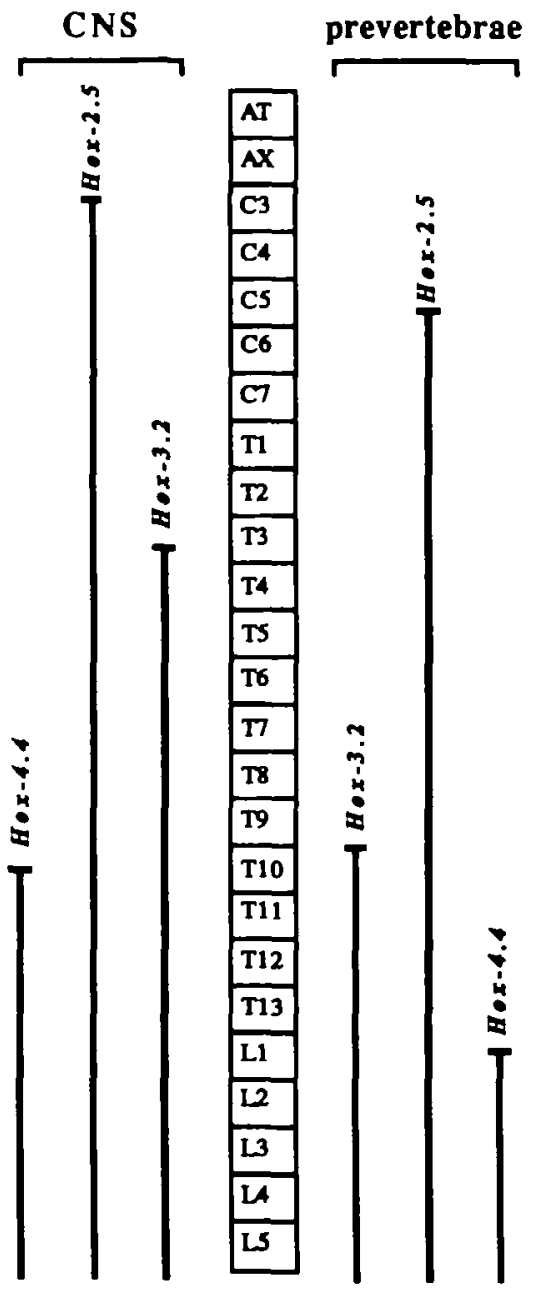

paralogs: Hox-1.7, $-2.5,-3.2$ and -4.4 related to Drosophila Abd-B

\author{
Hox-1.7: CNS \\ kidney \\ spinal cord \\ heart \\ soleen
}

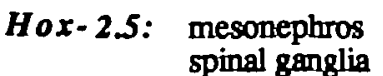

kidney

spinal cord

Hox-3.2: hindlimb buds kidney mesonephros genital ridge? spinal ganglia

Hox-4.4: limb buds mesonephros genital ridge spinal ganglia

\section{kidney \\ testis \\ ovary}

protocol, transcripts were detectable in the neural tube up to the first cervical prevertebra (Fig. $4 \mathrm{G} / \mathrm{H}$ ), which extends the previously published results to the anterior side (Awgulewitsch et al. 1986; Breier et al. 1988; Le Mouellic et al. 1988). Recently, Hox-3.1 protein expression was shown to be restricted in the neural tube caudal to the 4th prevertebra (Awgulewitsch and Jacobs, 1990).

As mentioned above, expression of Hox -3.2 in the mouse starts at 8.5 days of gestation in the region of the allantois. Expression in prevertebrae is best seen at day 12.5 caudal to the 9th thoracic prevertebra but is significantly lower than in the neural tube. This situation is comparable with other homeobox genes, where usually the expression in mesoderm-derived structures is restricted to more posterior domains than in ectoderm-derived structures. However, the relative levels of expression of the Hox genes in neuroectoderm and mesoderm varies slightly. For instance Hox-1.1 expression is stronger in somitic mesoderm than neuroectoderm (Püschel et al. 1990). From day 8.5 till day 12.5 , it appears that besides the prevertebrae the entire very posterior tail region is weakly positive for
Fig. 7. Comparison of the expression pattern of $H o x-3.2$ and its paralogs Hox-1.7, Hox-2.5 and Hox$4.4(-5.2)$. Expression domains and anterior boundaries of expression in the neural tube and prevertebrae are shown on the left side of the figure. On the right side the expression in developing organs during embryogenesis and in adult mouse tissues are shown (for references see Results).
Hox-3.2 expression, a pattern which is also seen with Hox-3.1. In the developing kidney transcripts are first seen at day 12.5 in metanephros and at later stages mainly in the cortex. Kidney is also the only adult tissue that expresses all murine paralogs of Hox-3.2 (Fig. 7).

\section{Comparison of the Hox-3.2 expression pattern with} other homeobox genes

Two interesting conclusions can be drawn by comparison of the Hox-3.2 expression pattern with the patterns of other homeobox genes. First, the domains of expression of the paralogous genes in the four clusters, Hox $-1.7,-2.5,-3.2$ and $-4.4(-5.2)$ are substantially different in the CNS and prevertebral column (summarized in Fig. 7). This differs from the findings for Hox$1.4,-2.6$, and $-4.2(-5.1)$ as well as Hox $-1.3,-2.1$ and -3.4 , which show not identical but very similar anterior boundaries of expression in the CNS and prevertebral column (Gaunt et al. 1989; 1990). Thus, as already suggested by Gaunt and coworkers, paralogs at the $5^{\prime}$ end of the clusters and therefore expressed more caudal in the embryo, may not show similar transcript distributions along the anteroposterior axis. 
The second interesting observation is obtained by comparing the expression patterns of homeobox-genes within their clusters. The dorsoventral expression pattern on transverse sections through the neural tube seems to be very similar for genes within the Hox-2 cluster (Holland and Hogan, 1988; Shughart et al. 1988; Graham et al. 1988; Bogarad et al. 1989). This holds true for the Hox-3 cluster if one compares Hox-3.1, Hox-3.2 and $H o x-3.4$ at day 12.5 p.c. They all show a similar transcript distribution in transverse sections, where $H o x-3.1$ and Hox-3.4 are very strongly expressed in the mantle layer but considerably weaker in the ependymal layer (Awgulewitsch et al. 1986; Breier et al. 1988; LeMouellic et al. 1988; Gaunt et al. 1990). At day 14.5 of gestation, however, Hox-3.1 and Hox-3.2 show unique patterns of expression. Hox-3.1 is expressed abundantly in the dorsal horns of the neural tube, whereas Hox-3.2 is not or only very weakly expressed in this region. Hence, genes within one cluster do not necessarily show an identical dorsoventral distribution of transcripts. In this respect, it will be very interesting to see which expression pattern Hox-3.4 and Hox-3.3 (first described as Hox-6.1, Sharpe et al. 1988) exhibit at day 14.5 of gestation.

In summary, Hox-3.2 shows a restricted expression pattern in the posterior part of the developing embryo. Apart from the neural tube, where expression seems to be restricted to postmitotic cells, transcripts are detected in spinal ganglia, prevertebrae and the developing kidney. These results are in agreement with the finding that genes located $5^{\prime}$ in the homeobox gene clusters are expressed more posterior than genes from the $3^{\prime}$ region. Hox-3.2 belongs to the Hox-1.7 subfamily. None of the homeobox gene subfamilies described to date vary as drastically in the anteroposterior transcript distribution in CNS and prevertebrae as Hox-1.7 and its paralogs. Furthermore this subfamily shows some other striking similarities, i.e. highest homology to the Drosophila $A b d-B$ gene, lack of the hexapeptide and noninducibility by RA in F9 EC cells. This raises the question of whether this is a unique feature for genes in the $5^{\prime}$ region of the Hox clusters. Several genes $5^{\prime}$ to the Hox-1.7 subfamily have already been isolated in all four clusters either in human or in mouse (for review see Kessel and Gruss, 1990 b). Thus it will be soon possible to elucidate whether these genes show similar characteristics and like Hox-3.2 and its paralogs, differ from genes located in the $3^{\prime}$ region of the clusters.

We thank Bernhard Herrmann for providing the cosmid containing Hox-3.2 genomic sequences and Karen Fahrner and Brigid Hogan for providing the $\lambda$ gt $10 \mathrm{cDNA}$ library. We also thank Claudia Walther, Susanne Dietrich and Philippe Duprey for Northern blots, Ralf Altschäffel for photographic work and Michael Kessel, Andreas Püschel and Rudi Balling for helpful comments on the manuscript. J.R.E. and M.G. were supported by the Max-Planck-Society.

\section{References}

Acampora, D., D'Espostto, M., Faiella, A., Pannese, M.,
Migliaccio, E., Morelli, F., Stornaiuolo, A., Nigro, V., Simeone, A. ANd Boncinelli, E. (1989). The human HOX gene family. Nucl. Acids Res. 17, $10385-10402$.

AKAM, M. (1987). The molecular basis for metamenc pattern in the Drosophila embryo. Development 101, 1-22.

Акам, M. (1989). Hox and HOM: Homologous gene clusters in insects and vertebrates. Cell 57, 347-349.

Altman, J. And Bayer, S. A. (1984). The development of the rat spinal chord. In Advances in Anatomy, Embryology and Cell Biology (ed. Beck, F., Hild, W., van Limborgh, J., Ortmann, R., Pauly, J. E. and Schiebler, T. H.) 85, New York, SpringerVerlag.

Ausubel, F. M., Brent, R., Kingston, R. E., Moore, D. D., Seidmann, J. G., Smith, J. A. and Struhl, K. (1989). Curr. Protoc. Mol. Biol., Wiley and Sons, Boston, Vol. I, pp. 4.2.1-4.2.5.

AWgulewTSCH, A. AND JACOBS, D. (1990). Differential expression of Hox-3.1 protein in subregions of the embryonic and adult spinal cord. Development 108, 411-420.

A wgulewitsch, A., Utset, M. F., Hart, C. P., McGinnis, W. AND RUDDLE, F. H. (1986). Spatial restriction in expression of a mouse homeobox locus within the central nervous system. Nature 320, 328-335.

Balling, R., Mutter, G., Gruss, P. and Kessel, M. (1989). Craniofacial abnormalities induced by ectopic expression of the homeobox gene Hox-1.1 in transgenic mice. Cell 58, 337-347.

Baron, A., Featherstone, M. S., Hill, R. E., Hall, A., Galliot, B. and Duboule, D. (1987). Hox-1.6: A mouse homeo-box-containing gene of the Hox-1 complex. EMBO J. 6, $2977-2986$.

Bastian, H. and Gruss, P. (1990). A murine even-skipped homolog, $E v x-1$, shows a biphasic expression pattern during embryogenesis. EMBO J. 9, 1839-1852.

Birnstiel, M. L., Busslinger, M. and Strub, K. (1985). Transcription termination and $3^{\prime}$ processing: the end is in site! Cell 41, 349-359.

Bogarad, L. D., Utset, M. F., Awgulewttsch, A., Miki, T., HakT, C. P. ANd Ruddle, F. H. (1989). The developmental expression pattern of a new murine homeobox gene: Hox-2.5. Devl Biol. 133, 537-549.

Breier, G., Bucan, M., Francke, U., Colberg-Poley, A. M. and Gruss, P. (1986). Sequential expression of murine homeobox genes during F9 EC cell differentiation. EMBO J. 5, 2209-2215.

Breier, G., Dressler, G. R. ANd Gruss, P. (1988). Primary structure and developmental expression pattern of $H o x-3.1$, a member of the murine $H o x-3$ homeobox gene cluster. EMBO J. 7, 1329-1336.

Celniker, S. E., Keelan, D. J. and Lewis, E. B. (1989). The molecular genetics of the bithorax complex of Drosophila: characterization of the products of the Abdominal-B domain. Geres and Dev. 3, 1424-1436.

Cho, K. W. Y., Goetz, J., Wright, C. V. E., FrtTz, A. Harwicke, J. and DeRobertis, E. M. (1988). Differential utilization of the same reading frame in a Xenopus homeobox gene encodes two related proteins sharing the same DNAbinding specificity. EMBO J. 7, 2139-2149.

Colberg-Poley, A. M., Voss, S. D., Chowdhury, K. and Gruss, P. (1985a). Structural analysis of murine genes containing homeobox sequences and their expression in embryonal carcinoma cells. Nature 314, 713-718.

Colberg-Poley, A. M., Voss, S. D., Chowdury, K., Stewart, C. L., Wagner, E. F. AND Gruss, P. (1985b). Clustered homeoboxes are differentially expressed during murine development. Cell 43, 39-45.

Courey, A. J., Hotzman, D. A., Jackson, S. P. and TJan, R. (1989). Synergistic activation by the glutamine-rich domains of human transcription factor Sp1. Cell 59, 827-836.

Desplan, C., Theis, J. and O'Farrell, P. H. (1985). The Drosophila developmental gene, engrailed, encodes a sequence specific DNA binding activity. Nature 318, 630-635.

Dollé, P. AND Duboule, D. (1989). Two gene members of the murine $H o x-5$ complex show regional and cell-type specific expression in developing limbs and gonads. $E M B O \mathrm{~J} .8$, 1507-1515. 
Dony, C. AND Gruss, P. (1987). Specific expression of the Hox1.3 homeobox gene in murine embryonic structures originating from or induced by the mesoderm. EMBO J. 6, 2965-2975.

Dressler, G. R. and Gruss, P. (1989). Anterior boundaries of Hox gene expression in mesoderm-derived structures correlate with the linear gene order along the chromosome. Differentiation 41, 193-201.

Duboule, D., Baron, A., Mahl and Galliot, B. (1986). A new homeobox is present in overlapping cosmid clones which define the mouse Hox-1 locus. EMBO J. 5, 1973-1980.

Duboule, D., Boncinelli, E., DeRobertis, E., Featherstone, M., Lonal, P., Oliver, G. and Ruddle, F. H. (1990). An update of mouse and human Hox genes nomenclature. Genomics (in press).

Duboule, D. ANd Dollé, P. (1989). The structural and functional organization of the murine Hox gene family resembles that of Drosophila homeotic genes. EMBO J. 8, 1497-1505.

Fahrner, K., Hogan, B. L. M. and Flavell, R. A. (1987). Transcription $H-2$ and $Q a$ genes in embryonic and adult mice. EMBO J. 6, 1265-1271.

Fainsod, A., Bogarad, L. D., Ruusala, T., Crothers, D. M. AND Ruddle, F. H. (1986). The homeodomain of a murine protein binds 5 ' to its own homeobox. Proc. natn. Acad. Sct. USA 83, 9532-9536.

Feinberg, A. P. and Vogelstein, B. (1983). A technique for radiolabeling DNA restriction endonuclease fragments to high specific activity. Anal. Biochem. 132, 6-13.

Fibi, M., Zink, B., Kessel, M., Colberg-Poley, A. M., Chowdhury, K., Labert, S., Lehrach, H. and Gruss, P. (1988). Coding sequence and expression of the homeobox gene Hox-1.3. Development 102, 349-359.

Gaunt, S. J., Coletta, P. L., Pravtcheva, D. and Sharpe, P. T. (1990). Mouse Hox-3.4: homeobox sequence and embryonic expression patterns compared with other members of the Hox gene network. Development 109, 329-340.

Gaunt, S. J., Krumlauf, R. and Duboule, D. (1989). Mouse homeo-genes within a subfamily, $H o x-1.4,-2.6$ and -5.1 , display similar anteroposterior domains of expression in the embryo, but show stage- and tissue-dependent differences in their regulation. Development 107, 131-141.

Gaunt, S. J., Sharpe, P. T. And Duboule, D. (1988). Spatially restricted domains of homeogene transcripts in mouse embryos: Relation to a segmented body plan. Development 104 Supplement, $169-179$.

Gehring, W. J. (1987). Homeoboxes in the study of development. Science 236, 1245-1252.

Graham, A., Papalopulu, N. and Krumlauf, R. (1989). The murine and Drosophila homeobox gene complexes have common features of organisation and expression. Cell 57, 367-378.

Graham, A, Papalopulu, N., Lorimer, J., McVey, J. H., Tuddenham, E. G. D. and KRUmlauf, R. (1988). Characterization of a murine homeobox gene, Hox-2.6, related to the Drosophila Deformed gene. Genes and Dev. 2 , 1424-1438.

Hart, C. P., Awgulewitsch, A., Fainsod, A., McGinnis, W. AND RUDDle, F. H. (1985). Homeobox gene complex on mouse chromosome 11: molecular cloning, expression in embryogenesis and homology to a human homeo box locus. Cell 43, 9-18.

HoEy, T. And LeVINe, M. (1988). Divergent homeobox proteins recognize similar DNA sequences in Drosophila. Nature 332, 858-861.

Hogan, B. L. M., Constantini, F. And Lacy, E. (1986). Manipulating the Mouse Embryo: A Laboratory Manual, Cold Spring Habour, New York: Cold Spring Habour Laboratory, pp. 228-235.

Hogan, B. L. M., Taylor, A. and Adamson, E. D. (1981). Cell interaction modulates embryonal carcinoma cell differentiation into parietal visceral endoderm. Nature 291, 235-237.

Holland, P. W. H. and Hogan, B. L. M. (1988). Spatially restricted patterns of expression of the homeobox-containing gene Hox-2.1 during mouse embryogenesis. Development 102, $159-174$.

Kappen, C., Shughart, K. and Ruddle, F. H. (1989). Two steps in the evolution of Antennapedia class vertebrate homeobox genes. Proc. natn. Acad. Sci. USA 86, 5459-5463.

Kessel, M., Balling, R. ANd Gruss, P. (1990). Variations of cervical vertebrae after expression of a Hox-1.1 transgene in mice. Cell 61, (in press).

Kessel, M., Fibi, M. ANd Gruss, P. (1988). Organization of homeodomain proteins. In Cellular Factors in Development and Differentiation, (Sato, G. H. and Harris, S. E. eds), Alan R. Liss, New York.

Kessel, M. ANd Gruss, P. (1990). Murine developmental control genes. Science, (in press).

Kessel, M., Schulze, F., Fibi, M. and Gruss, P. (1987). Primary structure and nuclear localization of a murine homeodomain protein. Proc. natn. Acad. Sci. USA 84, 5306-5310.

KozAK, M. (1978). How do eukaryotic ribosomes select initiation regions in messenger RNA? Cell 15, 1109-1123.

KozAK, M. (1983). Protein synthesis initiation. Microbiol. Rev. 47, $1-45$.

KozAK, M. (1986). Bifunctional messenger RNAs in Eukaryotes. Cell 44, 283-292.

Krumlauf, R., Holland, P. W. H., McVey, J. H. and Hogan, B. L. M. (1987). Developmental and spatial patterns of expression of the mouse homeobox gene, Hox-2.1. Development 99, 603-617.

Laughon, A. And Scort, M. P. (1984). Sequence of a Drosophila segmentation gene: protein structure homology with DNA binding proteins. Nature 310, 25-31.

Le Mouellic, H., Condamine, H. and Brulet, P. (1988). Pattern of transcription of the homeo gene Hox-3.1 in the mouse embryo. Genes and Dev. 2, 125-135.

MartiN, G. R. (1980). Teratocarcinoma and mammalian embryogenesis. Science 209, 768-776.

McDonald, P. M., Ingham, P. and Struhl, G. (1986). Isolation, structure and expression of even-skipped: a second pair-rule gene of Drosophila containing a homeobox. Cell 47, 721-734.

McGinnis, W., Garber, R. L., Wirz, J., Kuroiwa, A. AND Gehring, W. J. (1984). A homologous protein-coding sequence in Drosophla homeotic genes and its conservation in other metazoans. Cell 37, 403-408.

Meulink, F., de LaAf, R., Verruzer, P., Destree, O., Kroezen, V., Hilkens, J. AND Dechamps, J. (1987). A mouse homeobox containing gene on chromosome 11: sequence and tissue-specific expression. Nucl. Acids Res. 15, 6773-6786.

Nornes, H. O. AND Carry, M. (1978). Neurogenesis in the spinal cord of the mouse: an autoradiographic analysis. Brain Res. 159, 1-16.

Nornes, H. O., Dressler, G. R., Knapik, E. W., Deutsch, U. AND Gruss, P. (1990). Spatially and temporally restricted expression of Pax2 during murine neurogenesis. Development, 109, 797-.

Odenwald, W. F., Taylor, C. F., Palmer-Hill, F. J., Friedrich, V., JR, TANi, M. and Lazzarini, R. A. (1987). Expression of a homeodomain protein in noncontact-inhibitid cultured cells and postmitotic neurons. Genes and Dev. 1, 482-496.

Otting, G., Qian, Y. Q., Müller, M., Affolter, M., Gehring, W. J. AND WUTHRICH, K. (1988). Secondary structure determination for the Antennapedia homeodomain by nuclear magnetic resonance and evidence for a helix-turn-helix motif. EMBO J. 7, 4305-4309.

PUschel, A. W., Balling, R. and Gruss, P. (1990). Positionspecific activity of the Hox-1.1 promotor in transgenic mice. Development 108, 435-442.

Qian, Y., Billeter, G., Otting, G., Muller, M., Gehring, W. J. AND WUThrich, K. (1989). The structure of the Antennapedia homeodomain determined by NMR spectroscopy in solution: comparison with procaryotic repressors. Cell 59, 573-580.

Regulewski, M., Harding, K., Kostriken, R., Karch, F., LeVine, N. AND McGinnes, W. (1985). Homeobox genes of the Antennapedia and Bithorax complex of Drosophila. Cell 43, $71-80$.

Rubin, M. R., King, W., Toth, L. E., Sawczuk, I. S., Levine, M. S., D'Eustachio, P. and Nguyen-Huu, M. C. (1987). Murine Hox-1.7 homeobox gene: cloning, chromosomal location and expression. Molec. cell. Biol. 7, 3836-3841, 5593. 
Sanger, M. P., Nicklen, S. and Coulsen, A. R. (1977). DNA sequencing with chain termination inhibitors. Proc. natn. Acad. Sci. USA 74, 5463-5467.

SCHNeuWly, S., Kuroiwa, A., Baumgartner, P. AND Gehring, W. J. (1986). Structural organisation of the homeotic gene Antennapedia of Drosophila melanogaster. EMBO J. 5, 733-739.

ScotT, M. P. AND Weiner, A. J. (1984). Structural relationships among genes that control development: sequence homology between the Antennapedia, Ultrabithorax and fushi tarazu loci of Drosophila. Proc. natn. Acad. Sci. USA 81, 4115-4119.

Shapiro, M. B. and Senapathy, P. (1987). RNA splice junctions of different classes of eukaryotes: sequence statistics and functional implications in gene expression. Nucl. Acids Res. 15, 7155-7174.

Sharpe, C. R., Fritz, A., DeRobertis, E. M. and Gurdon, J. B. (1987). A homeobox-containing marker of posterior neural differentiation shows the importance of predetermination in neural induction. Cell 50, 749-758.

Sharpe, P. T., Miller, J. R., Evans, E. P., Burtenshaw, M. D AND GAUNT, S. J. (1988). Isolation and expression of a new mouse homeobox gene. Development 102, 397-407.

Schughart, K., Kappen, C. and Ruddle, F. H. (1988). Mammalian homeobox-containing genes: genome organization, structure, expression and evolution. Br. J. Cancer 58, Suppl. IX, 9-13.
Shughart, K., Utset, M. F., Awgulewttsch, A. ANd Ruddle, F. H. (1988). Structure and expression of Hox-2.2, a murine homeobox-containing gene. Proc. natn. Acad. Sci. USA 85 $5582-5586$.

Simeone, A., Acampora, D., Arcion, L., Andrews, P. W., Boncinelli, E. ANd Mavilo, F. (1990). Human $H O X-2$ homeobox genes are sequentially activated by retinoic acid in embryonal carcinoma cells. submitted.

STRICKLAND, S. (1981). Mouse teratocarcinoma cells: prospects for the study of embryogenesis and neoplasia. Cell 24, 277-278.

WENTWORTH, L. E. (1984a). The development of the cervical spinal cord of the mouse embryo. I. A golgi analysis of ventral root neuron differentiation. J. comp. Neurol. 222, 81-95.

WENTWORTH, L. E. (1984b). The development of the cervical spinal cord of the mouse embryo. II. A golgi analysis of sensory, commissural and association cell differentiation. J. comp. Neurol. 222, 96-115.

Wright, C. K. E., Cho, K. W. Y., Hardwicke, J., Collins, R. AND DE RoBERTIS, E. H. (1989). Interference with function of a homeobox gene in Xenopus embryos produces malformations of the anterior spinal cord. Cell 59, 81-93. 